\title{
Vineyards genetic monitoring and Vernaccia di San Gimignano wine molecular fingerprinting
}

\author{
Monica Scali $^{1}$, Paolucci Elisa ${ }^{1}$, Bigliazzi Jacopo ${ }^{2}$, Cresti Mauro ${ }^{2}$, Rita Vignani $^{2 *}$ \\ ${ }^{1}$ Department of Life Science, University of Siena, Siena, Italy \\ ${ }^{2}$ Serge-genomics s. r. l., Department of Life Science, University of Siena, Siena, Italy \\ Email: ‘rita.vignani@unisi.it
}

Received 13 November 2013; revised 22 December 2013; accepted 15 January 2014

Copyright (C) 2014 Monica Scali et al. This is an open access article distributed under the Creative Commons Attribution License, which permits unrestricted use, distribution, and reproduction in any medium, provided the original work is properly cited. In accordance of the Creative Commons Attribution License all Copyrights (c) 2014 are reserved for SCIRP and the owner of the intellectual property Monica Scali et al. All Copyright (C) 2014 are guarded by law and by SCIRP as a guardian.

\section{ABSTRACT}

The definition of the genetic profile of Vernaccia di San Gimignano (VSG) in the areas of production is an essential step for both the implementation of a plan of analytical traceability and the evaluation of the biological future potential of the same grape variety in relation to any environmental change. The genetic variability of the VSG was monitored by use of SSRs genotyping of a representative portion of individuals belonging to both the productive vineyards and the germplasm collections that represent the “mother plants" reservoir for future vineyards. $\mathbf{7 4 \%}$ of the individuals have been shown to be identical to the grapevine genotype reported in databases as VSG truetype. In order to determine the wine varietal composition by DNA analysis, four wine types commercialized as VSG were DNA-tested at 14 loci SSRs. The molecular data obtained demonstrate the presence as prevalent component of the VSG in the four wine types. All the wines revealed the presence of minor varieties, whose presence/absence was estimated by extrapolating the allele configuration that best matched to a standard genotype. Molecular data allow us to exclude the presence of three aromatic white grapevines that are not allowed by the actual production rules (Disciplinare di Produzione).

\section{KEYWORDS}

Vitis vinifera L.; SSRs Genotyping; Vernaccia di San Gimignano; Wine DNA; Molecular Traceability

\section{INTRODUCTION}

The Vernaccia di San Gimignano (VSG) is one of the

\footnotetext{
*Corresponding author.
}

oldest Italian wines that can boast an international circulation and worldwide fame. It is traditionally made with grapes that take the same name grown in a small area of Tuscany between Siena, Pisa and Florence coinciding with the municipality of San Gimignano in a total area of only 770 hectares. It is therefore a grapevine with limited circulation. It is traditionally considered a native Tuscan grapevine, although many assumptions based on historical investigations concerning the VSG make its etymology and historical and geographical origin still uncertain [1].

The recent implementation of the quality policy in the wine sector has given strong impetus to the restoration and enhancement of local products that are closely related to their area of origin.

Despite numerous studies aimed at the characterization of molecular character of so-called minor or native Tuscan grape varieties [2,3], the profile of the grapevine VSG has been only partially characterized and mainly from the historical [4] ampelographic [5,6] and enological point of view [7].

The definition of a genetic profile representative of the grape production areas is an essential step to study the genetic variability of a population in the field and allows managing the future biological potential of a variety in relation to environmental changes. Moreover, this represents the first milestone in the implementation of an innovative plan for the molecular control of wine production linked to a specific territory.

Recent publications [8] described the VSG as a synonym of the Ligurian grape variety Piccabón and the Tuscan Canaiolo Bianco. However, an accurate ampelographic description of the variety Piccabón was not produced. Other studies [9,10] correlated the VSG with Canaiolo Bianco (Drupeggio, Vernaccia or Uva rosa) that was analyzed thoroughly in a recent monitoring work 
conducted both by molecular and ampelometric methods. Here, the authors demonstrate that the Canaiolo Bianco truetype in Tuscany is identical to the Umbrian grape known as Drupeggio, and distinct from the VSG.

The study of genetic and morphological complexity of the many grape varieties populations is not so much found in the official grapevine germplasm collections consisting of individuals "types" characterized in fine detail and propagated under controlled conditions from a few mother plants. On the other hand, the analysis of productive or historical vineyards, often leads to the observation of structured populations, composed of individuals of considerable age and uncertain identity and origin, that might have been propagated by amateur grapevine growers regardless of the necessary guarantees that are nowadays usually required for planting new vineyards, according to national and international phytosanitary and genetic requirements. For this reason, the analysis of the genetic variability of productive historians vineyards may appear far more complex than one might assume on the basis of studies conducted in germplasm collections. Moving from this point of view, the study on the VSG has started with the need to define the degree of genetic variability of the vineyards from which it is currently produced the wine VSG. In more detail, the existence of a truetype VSG grape in the production area, has allowed us to detect the possible presence of grapevines that do not comply with VSG, the existence of biotypes/ ecotypes from slightly different features attributable to the main grapevine, and no less important, allowed to set up a plan of molecular traceability "from-vineyard-to thebottle”.

Current regulations for the various sectors of the agrifood industry have already validated the molecular traceability methods, which make use of several PCR applications, including Real-time Polymerase Chain Reaction (RT-PCR) for detecting pathogenic microorganisms $[11,12]$ or for tracing GMOs (Genetically Modified Organisms) $[13,14]$ in several food matrices. Molecular methods have, for quite some time now, even been used for authenticating animal breeds and vegetable varieties in order to increase the value of the quality certification PGI (Protected Geographical Indication) and PDO (Protected Designation of Origin) of products obtained from them [15]. The majority of molecular characterization methods use PCR amplification of molecular markers, among which the more widely used for the grapevine in the last twenty years are the SSRs (Simple Sequence Repeats).

Indeed, the genetic testing at SSRs markers has already become a recommended protocol of the Organisation Internationale de la Vigne et du Vin (OIV, International Vine and Wine Organisation) for certifying new material in the propagation phase.

The ability to use genetic information still contained within the wine DNA for variety determination has been the subject of recent publications $[16,17]$. In mono-varietal wines the opportunity to genotype DNA from wine, using SSRs markers, allows us to obtain the genetic identity of the original grapevine [18].

In order to monitor the genetic variability of VSG populations and identify the genotypic profile that best characterizes the VSG, 183 grapevines from the productive vineyards and 79 grapevines, representing 8 of the 13 existing clones, from the germplasm collection fields, are characterized using 7 SSRs markers. In order to explore some of the assumptions derived from historical and geographical hints, the genotypic profile of VSG was compared with that of 33 grapevines spread in different parts of Italy (Liguria, North West Italy; Campania, South Italy, Tuscany, Central Italy) as well as others having diffusion in grapevine growing countries, such as France, Germany and Spain. To trace the identity of the VSG in the relative products, 4 wine types of VSG, were analyzed for their varietal composition by amplification of residual DNA using a panel of 14 SSRs markers. This is to our knowledge the first paper reporting data on varietal composition of a blended white wine by use of molecular markers.

\section{MATERIALS AND METHODS}

\subsection{Plant Material}

183 grapevines registered as VSG in the area of production of VSG were taken from 8 farms in the municipality of San Gimignano (Siena Italy), for a total of 10 vine plots. In addition, 79 samples were taken from the "grapevine germplasm collection” (Azienda Agricola Fratelli Vagnoni, San Gimignano, Siena), which encounters 8 registered clones of VSG (VCR 2, 3, 5, 13, 15, 16, 17, 19; Cooperative Nurseries Rauscedo, Pordenone, Italy). The leaf material collected, was stored at $+4^{\circ} \mathrm{C}$ prior to DNA extraction. The reference VSG plant and the grapevines used in the present study were kindly provided by the CRA-VIT (Conegliano Veneto, Treviso, Italy).

\subsection{Plant DNA Extraction}

The genomic DNA was extracted from $100 \mathrm{mg}$ of leaf tissue using a X-Robot tractor (Corbett Robotics, AU) using the Qiagen DNeasy Plant Kit with optimized protocol for Vitis vinifera L. [18].

The amount of extracted DNA was checked by gel electrophoresis and incorporation of ethidium bromide, in standard conditions, comparing the results with the parameters obtained from the absorbance spectrophotometer readings $(\lambda=260 / 280 \mathrm{~nm})$. 


\subsection{Wine DNA Extraction}

Four commercial VSG wines (year of production 2010) brought to the Serge-genomics laboratories, for a blindtesting by the "Consorzio della Denominazione San Gimignano", were processed for DNA extraction after storage at $+10^{\circ} \mathrm{C}$. Since it was a blind test the wine samples were arbitrarily numbered from 1 to 4 . All samples were processed in triplicates.

All the samples were processed according to the method published earlier, with the only technical improvement of precipitating the wines at $-80^{\circ} \mathrm{C}$ [18].

\subsection{Quantifying DNA Yield by Real-Time PCR}

A TaqMan probe designed on the endogenous 9-cisepoxycarotenoid dioxygenase (NCED2) gene [16] region was used to quantify the Vitis vinifera L. DNA extracted from wine.

The Real-time PCR experiments were carried out using an iCycler iQ5 SYBR Green detection chemistry on 96-well reaction plates (Bio-Rad, Hercules, CA, USA).

The reaction mixture, in a total volume of $20 \mu \mathrm{L}$, contained: $2 \mu \mathrm{L}$ of DNA, $0.6 \mu \mathrm{L}$ each primer (300 nM each) VVMD25, $10 \mu \mathrm{L}$ of iQ SYBR Green Supermix (BioRad), and $8 \mu \mathrm{L}$ of RNase/DNase-free sterile water. Each reaction was run in triplicate, as was the no-template control.

A melting curve analysis was performed with the temperature increasing from $56^{\circ} \mathrm{C}$ to $95^{\circ} \mathrm{C}$. In order to make data collected from different experimental plates comparable, the threshold values were manually set to the value corresponding to the arithmetic mean between the automatically generated thresholds determined by the Bio-Rad iQ5 Software 2.1 (Bio-Rad).

For quantification with the probes we used $20 \mu \mathrm{L}$ reaction volume containing: $2 \mu \mathrm{L}$ of DNA, $0.6 \mu \mathrm{L}$ of each primer (300 nM), $8 \mu \mathrm{L}$ of iQSuperMix for Probes (BioRad), $0.4 \mu \mathrm{L}$ of NCED2 probe [16] and $8.4 \mu \mathrm{L}$ of RNase/ DNase-free water.

The reaction schedule comprises a denaturation cycle of $10 \mathrm{~min}$ at $95^{\circ}$, a second step of 50 cycles which entails an initial phase of $95^{\circ} \mathrm{C}$ for $15 \mathrm{sec}$, and a successive annealing/polymerization step at $61^{\circ} \mathrm{C}$ for $45 \mathrm{sec}$.

For each genomic DNA sample, the copy numbers of the endogen gene (NCED2) was calculated by the iCycler iQ optical System Software, version 2.1a (Biorad), as mean values of the three replicate threshold cycles $\left(\mathrm{C}_{\mathrm{t}}\right)$ on the basis of the standard curves obtained.

\subsection{SSRs Genotyping}

The VSG genotype was obtained by amplifying the genomic DNA at the following SSRs loci: VVMD7, VVMD25, VVMD27, VVMD34, VVMD36 [19], VVS2 [20] VrZag 79 [21]. PCR reactions were carried out in an
Eppendorf Mastercycler gradient PCR in a total volume of $12.5 \mu \mathrm{l}$ containing $2.5 \mu \mathrm{l}$ of genomic DNA, $0.25 \mathrm{mM}$ dNTPs, $0.25 \mu \mathrm{M}$ each primer (one of them being fluorescein labeled), 1X Green GoTaq Reaction Buffer containing $1.5 \mathrm{mM} \mathrm{MgCl}_{2}, 0.1 \mathrm{U}$ Go Taq DNA Polymerase (Promega). For the Vernaccia wines genotyping the following SSRs markers were PCR-amplified, targeting the wine DNA at 14 genomic markers: VVMD21, VVMD24, VVMD25, VVMD26, VVMD32, VVMD36 [19], VVMD7, VVMD27, VVMD34, VVS2 [20], VrZag21, VrZag47, VrZag79 and VrZag83 [21]. The same SSRs markers were used to genotype 15 grapevines (Chardonnay, Malvasia Bianca, Viognier, Manzoni bianco, Pinot bianco, Pinot grigio, Trebbiano toscano, Verdea o San Colombano, Verdicchio bianco, Vermentino, Sauvignon, Riesling, Semillon, Marsanne) possibly present in wines as minor components on the basis of their common distribution in the San Gimignano area and to genotype 7 aromatic grapevines (Traminer aromatico, Moscato bianco, Muller Thurgau, Malvasia bianca di Candia, Malvasia di Candia Aromatica, Malvasia istriana, Incrocio Bruni) that should not be present in the VSG wine, in agreement with the actual regulation ("Disciplinare di produzione della Vernaccia di San Gimignano" available at:

http://www.vernaccia.it/vernaccia-di-san-gimignano-disciplinare.aspx).

PCR conditions included an initial denaturation step of $5^{\prime}$ at $95^{\circ} \mathrm{C}, 39$ cycles of $30^{\prime \prime}$ at $95^{\circ} \mathrm{C}, 30^{\prime \prime}$ at $48^{\circ} \mathrm{C}-56^{\circ} \mathrm{C}$, $1^{\prime}$ at $72^{\circ} \mathrm{C}$ and a final extension of $10^{\prime}$ at $72^{\circ} \mathrm{C}$.

The PCR products were separated on $2 \%$ agarose gel stained with ethidium bromide to identify possible imperfections and to decrease the rate of failure in capillary electrophoresis.

$2 \mu \mathrm{l}$ of PCR product and $12.5 \mu \mathrm{l}$ of an internal size standard (Et-Rox-400, GE) were denatured at $95^{\circ} \mathrm{C}$ for 2 ' and kept on ice.

The allele sizing was done by capillary electrophoresis, based on laser scanning of fluorescence-marked DNA fragments. Genotyping was done on MegaBACE 500 DNA Analysis System fluorescent fragment analysis and evaluated by software FragmentProfiler version 1.2 (both by GE-Healthcare, Italy).

After collecting genotypes, a dendrogram of similarity was produced by NTSYS ver. 2.0 including the 33 grapevines listed at Table 1 . The prevalent geographic distribution of the 33 grapevines included in the analysis is reported in Figure 1.

\section{RESULTS}

\subsection{Genetic Variability in the VSG Population}

The sampling carried out in the producting vineyards of San Gimignano has allowed to survey the genetic variability of the VSG population. For this purpose, the 
Table 1. List of grapevines whose genotype is compared to the Vernaccia di San Gimignano truetype. W (White berry grapevines), $\mathrm{R}$ (Red berry grapevines).

\begin{tabular}{|c|c|c|}
\hline Grapevine & Berry color & Diffusion \\
\hline Aleatico & $\mathrm{R}$ & Italy (Tuscany) \\
\hline Moscato Bianco & $\mathrm{W}$ & Italy (North, Central, and Southern regions, including Tuscany) \\
\hline Moscato Montalcino & $\mathrm{W}$ & Italy (Tuscany) \\
\hline Malvasia Bianca & W & Malta, Tuscany \\
\hline Trebbiano Toscano & W & Italy (Tuscany) \\
\hline Sauvignon Gros & $\mathrm{W}$ & France \\
\hline Sauvignon & $\mathrm{W}$ & France \\
\hline Vermentino & $\mathrm{W}$ & Spain, Italy (Tuscany, Ligury, Sardinia) \\
\hline Vernaccia Oristano & $\mathrm{W}$ & Italy (Sardinia) \\
\hline Sangiovese & $\mathrm{R}$ & Italy (Tuscany, Emilia Romagna) \\
\hline Riesling Italico & $\mathrm{W}$ & Italy (Friuli Venezia Giulia) \\
\hline Grechetto & W & Greece (Campania, Lazio) \\
\hline Riminese di Porto Ercole & W & Italy (Tuscany) \\
\hline Verdicchio Bianco & W & Italy (Marche) \\
\hline Fiano & $\mathrm{W}$ & Italy (Campania) \\
\hline Vernaccia di San Gimignano (CRA-VIT-Conegliano) & $\mathrm{W}$ & Italy (Tuscany) \\
\hline Vernaccia di San Gimignano & W & Italy (Tuscany) \\
\hline Falanghina & $\mathrm{W}$ & Italy (Campania) \\
\hline Pinot Bianco & $\mathrm{W}$ & Germany \\
\hline Chardonnay Mouschet & W & France \\
\hline Manzoni Bianco & $\mathrm{W}$ & Italy (Veneto) \\
\hline Goldriesling & $\mathrm{W}$ & Germany \\
\hline Muller Thurgau & W & Germany \\
\hline Riesling & $\mathrm{W}$ & Germany \\
\hline Chardonnay & $\mathrm{W}$ & France \\
\hline Grenache Gris & G & Spain, France \\
\hline Grenache Velu & $\mathrm{R}$ & Spain, France \\
\hline Tocai Rosso & $\mathrm{R}$ & Italy (Friuli Venezia Giulia) \\
\hline Grenache Noire & $\mathrm{R}$ & Spain, France \\
\hline Grenache Blanc & $\mathrm{W}$ & Spain, France \\
\hline Alicante & $\mathrm{R}$ & Spain, Southern and Central Italy \\
\hline Cannonau & $\mathrm{R}$ & Spain, Italy (Sardinia) \\
\hline Greco di Tufo & W & Italy (Campania) \\
\hline Vernaccia Nera & $\mathrm{R}$ & Italy (Marche) \\
\hline
\end{tabular}




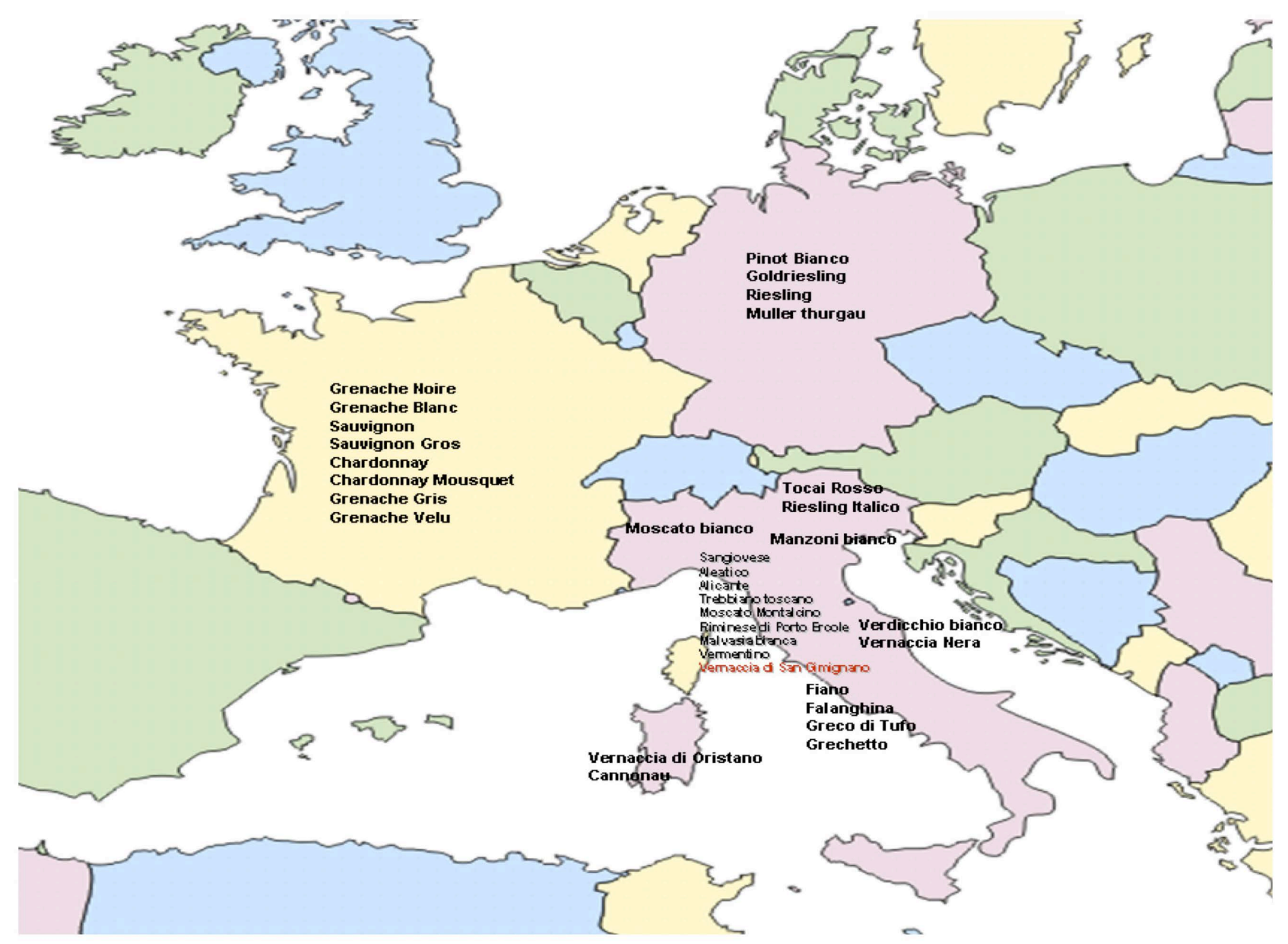

Figure 1. Prevalent geographic distribution of the grapevines used for genetic comparisons with the Vernaccia di San Gimignano.

genotypic profiles, reconstructed by amplification of genomic DNA loci to 7 SSRs were used for a comparative assessment of the intravarietal and intervarietal variability of the VSG. At the same time, by use of the same molecular method the main germplasm collection field collecting 8 of the 13 the commercially available clones of VSG was tested. The data shown in Figure 2(a) shows that $74 \%$ of the grapevines studied are genetically identical to the truetype VSG taken from the national collection of grapevine germplasm, while the observed differences in genotype are negligible for $25.6 \%$ of the population (varying between 1 emylocus and 2 loci +1 emylocus). A single individual genotyped in a productive vineyard, shows a difference that can be considered weakly significant (3 loci). Analyzing the landscape of genetic diversity in relation to the origin $(\mathrm{V}=$ Vineyards; GC = germplasm collection) we note that there is a greater overall variability in the vineyards (43/183 grapevines) compared to the germplasm collection fields (25/79 grapevines) (Figure 2(b)). Meanwhile, the total genotypic variability expressed as a percentage between the two subpopulations belonging to V and GC is respectively $23 \%$ and $31 \%$.
The picture of genetic variability characterizing the population of the VSG grapevines has allowed to establish that the majority of individuals currently used for the production of wine has a genetic profile identical to the VSG kept in the official collections of grapevine germplasm.

The VSG genotype has been placed in correlation with that of 33 other varieties from various sources and geographical origin (Figure 1) selected on the basis of possible correlations with the VSG. The analysis of the similarity dendrogram (Figure 3) reveals that the VSG genotypic profile shows a peculiar identity, abutting to a heterogeneous cluster of grapes which includes, among others, 4 white grapes and one red berry popular in Tuscany (Aleatico, Moscato Bianco, Moscato Montalcino, Malvasia Bianca, Sangiovese). The Moscato Bianco and the Moscato di Montalcino seem to be closely correlated with a high degree of similarity of over $82 \%$. Two French grape varieties, Sauvignon and Sauvignon Gros show a significant similarity with the Vermentino and Trebbiano toscano, respectively, two white grape varieties widely circulated in Tuscany. 


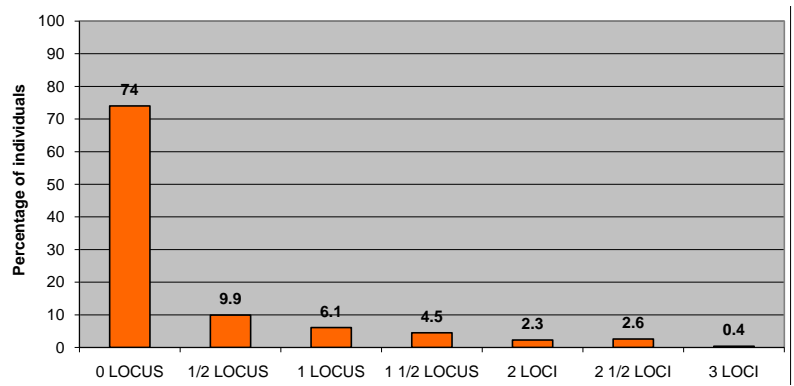

(a)

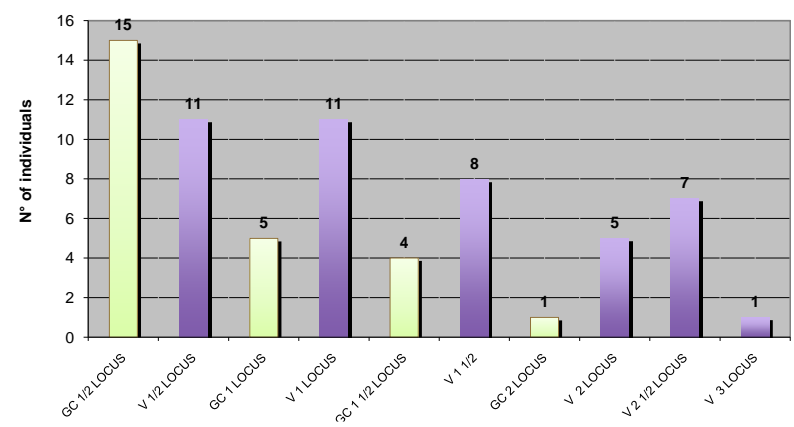

(b)

Figure 2. (a) Analysis of the genetic variability in the Vernaccia di San Gimignano population (V = Vineyards, GC = Germplasm Collection), measured as percentage of grapevines differing at progressive numbers of SSRs loci (from 0 to 3 loci). $74 \%$ of grapevines are genetically identical to San Gimignano truetype; (b) Number of grapevines $\left(\mathrm{N}^{\circ}\right)$ differing from the Vernaccia di San Gimignano truetype, in V and GC, respectively. As expected, the number of dissimilar grapevines is higher in V (43), than in the GC (25). The only weak, but significant difference (>3 loci) in genotype is found in one plant, sampled in a productive vineyard.

There are four varieties from Campania inset into confrontation with the VSG (Grechetto, Fiano, Falanghina and Greco di Tufo). Given that through the construction of the dendrogram is analyzed the relative genetic variability, it seems interesting that the genetic profile of the VSG is closer to Fiano, rather than to the grapevines widespread in Tuscany or the international ones previously described as etymologically related to it, such as the group of Grenache (G. Gris, G. Velu, G. Noire, G. Blanc) [23]. In particular, the Fiano approaches to genetically VSG showing a similarity of approximately $49 \%$.

Remarkably, with a similarity of over $80 \%$ are the Muller Thurgau and Riesling, while the Gold Riesling seems to more closely related the Manzoni Bianco. Finally, it is confirmed the genetic compactness of the group of Grenache, in relation to Alicante, Tocai Rosso and Cannonau, previously described in the literature as “collective grapevine name” [24]. The "Grenache” group, which shows in the semantics of the name a common historical root, might have evolved into highly correlated, but independent grapevines [24].

\subsection{Wine Varietal DNA Fingerprints Demonstrate the Presence of the VSG}

The DNA was successfully extracted from the wines in triplicates and quantified by RT-PCR. DNA average amount [2 ng/mL] Figure 4 was comparable to what previously demonstrated for monovarietal white wines [18]. Due to an average LCN (Low Copy Number) DNA template, this was immediately processed for PCR amplification at 14 SSRs markers in order to trace varietal components genotype. Amplified SSRs loci gave amplified PCR products in 13 cases of 14 (VVMD7 did not produce any amplification product). Raw data showing the allele size amplified respectively in each wine and the comparison with that of the VSG grapevine at four loci (VVS2, VVMD24, VVMD25 and VVMD36) is shown in Figure 5. The sum of validated alleles (observed in two among the three replicas of the same sample) were scored and listed in Table 2. The presence of the VSG in the wine is demonstrated for all wines, even if the statistical evidence based on the number of loci and emiloci shared with the standard, varies from a minimum weak strength of 4 loci +6 emiloci (wine type 3 ) to 5 loci +3 emiloci (wine type 1 and 2) and 8 loci +2 emiloci for the wine type 4 . Based on the same principle the following hypothesis could be formulated as concerns the minor varietal components that are listed in decreasing order of probability; wine type 1: Pinot bianco, wine type 2: Chardonnay, Semillon, Trebbiano toscano, Pinot Bianco; wine type 3: Chardonnay, Vermentino; wine type 4: Manzoni Bianco, Chardonnay, Riesling. With this panel of SSRs markers in all the wines the presence of three aromatic grapevines, Moscato Bianco, Malvasia di Candia Aromatica, Malvasia Istriana, could be excluded due to the absence in the wine of discriminant, identificative alleles univocally associated to them, within the grapevines panel tested.

\section{DISCUSSION}

Recent evidence demonstrates the high correlation of the VSG with grapevines from Ligury, the Piccábon while it seems truly peculiar and different from the Canaiolo Bianco $[8,9]$. Despite the evidence of synonymy between VSG and Piccábon, various studies proving the historical connections during the Middle Age between Ligury and Tuscany, it seems interesting that at molecular level the VSG that is grown today at San Gimignano, appears to be more similar to a grapevine from Campania, the Fiano, than to other regional Italian grapevines and other French, German or Spanish grapevines that are described as possibly associated to the VSG (e.g. Grenache). This piece of evidence might open a debate on the possible historical relationship of the VSG with grapevines from Southern Italy. The genetic variation in the VSG population 


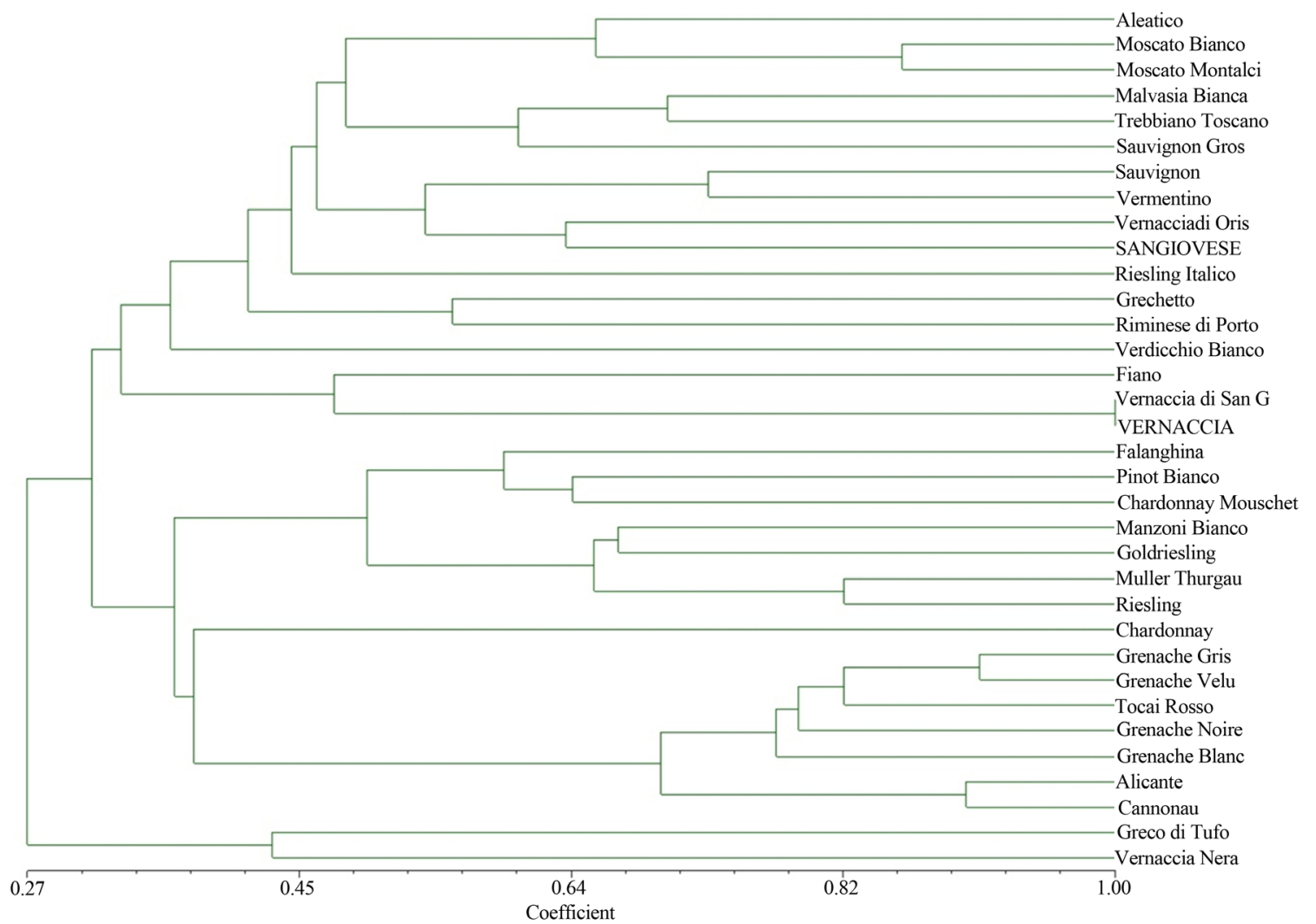

Figure 3. Dendrogram of similarity based on genotype profiling at of the Vernaccia di San Gimignano and 33 grapevines of different origin and geographical diffusion. "Vernaccia" in capitol letters identifies the representative genotype sampled at San Gimignano, compared to the standard Vernaccia di San Gimignano taken form the Susegana germplasm collection (CRA-VIT, Conegliano Vene- to). The Vernaccia di San Gimignano shows a moderate similarity with four white berry grapevines and a red one from Tuscany (Aleatico, Moscato Bianco, Moscato Montalcino, Malvasia Bianca, Sangiovese) Campania (Grechetto, Fiano, Falanghina and Greco di Tufo).

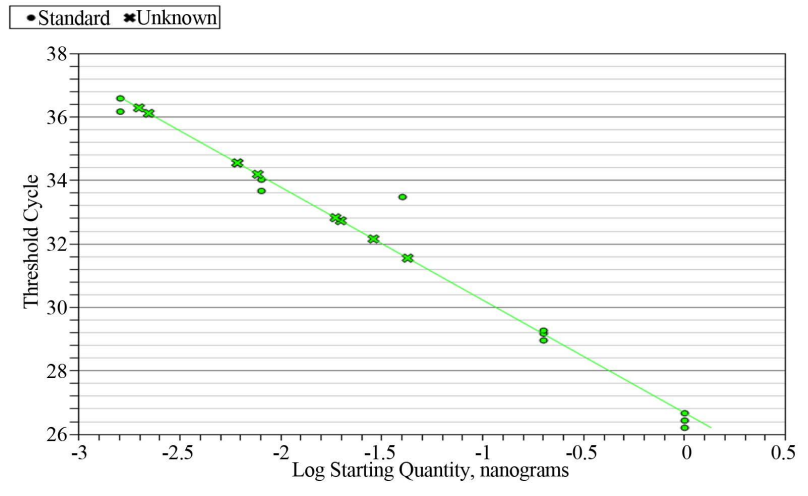

Figure 4. Vernaccia di San Gimignano wines DNA quantification obtained by RT-PCR. The wines were analyzed in duplicates (crosses identify unknown samples) and quantified with NCED2 TaqMan probe. The calibration curve was obtained with increasing genomic DNA quantities from a Sangiovese grapevine, ranging from 0.5 to $3 \mathrm{ng} / \mathrm{mL}$.

seems negligible, with the exception of those observed in the germplasm where the future mother plants for the VSG are collected. In this case, it would be desirable to extend monitoring to all the mother plants intended for propagation, for providing suitable and guaranteed material for the future vineyards. This interpretation of the molecular data provides insights to deepen links between the VSG and the genetic heritage of Campania and Lazio grapevines that would arise in connection with the VSG a sort of "Southern road" developed already in the classical period from the first century B.C. by the Greeks and Romans and that would have contributed to the spread of the grapevine from South to North. In fact, it was due to the consolidation of the power of the Roman Empire that viticulture was able to establish itself and spread at European level, moving from south to north up to affect France and Germany to the geographical areas of the Danube. The use of wine in the Mediterranean diet is part of a broader philosophy of life marked by a Latin style, where the wine is essential food, rich in healing properties and intended for everyday use and is opposed to an Anglo-Saxon concept that associates consumption wine primarily to specific events in nature or meditative ritual. The use of DNA as a key molecule in order to obtain information on the composition of varietal wines is still much debated in the scientific community. Untill a 


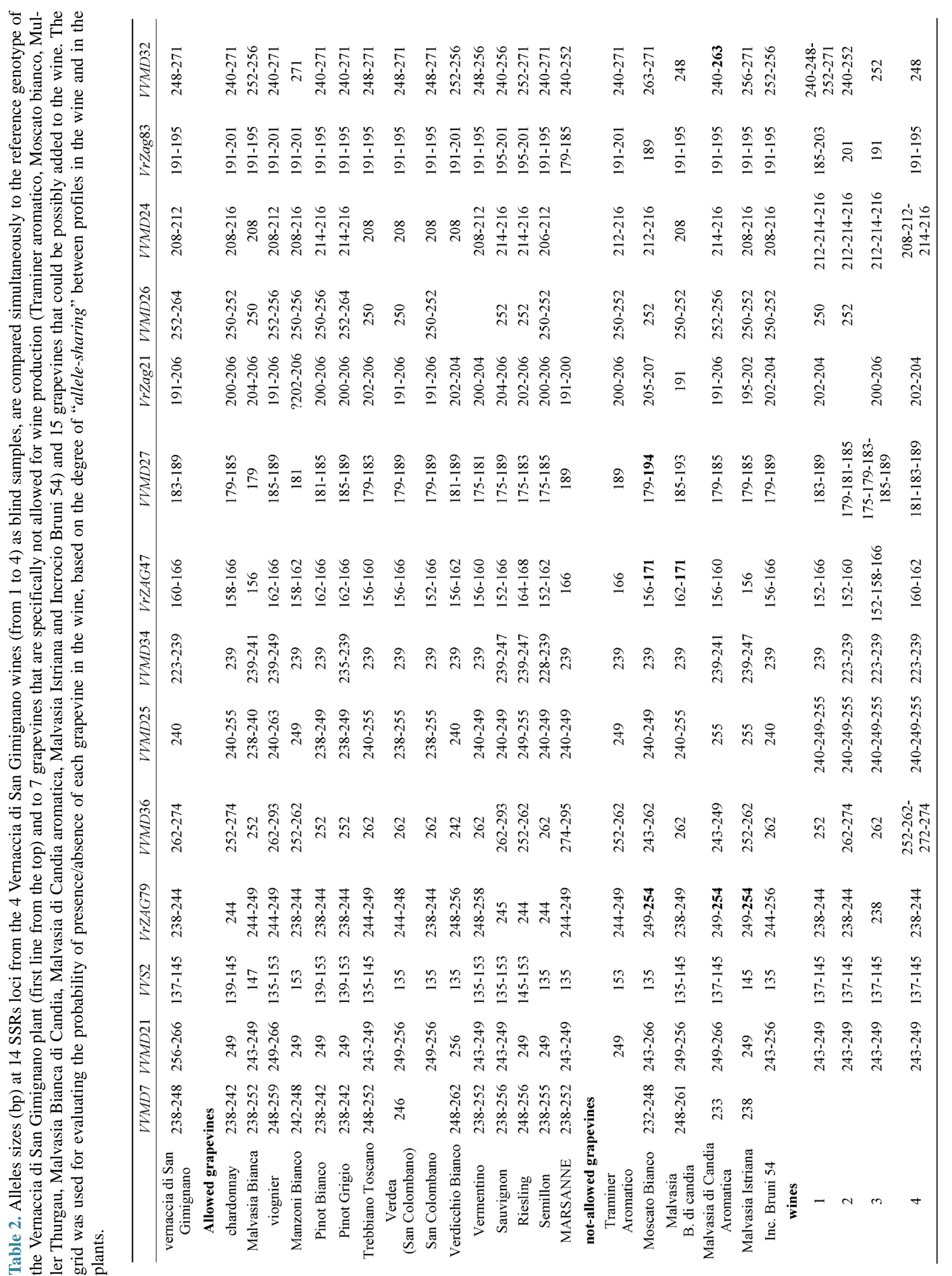




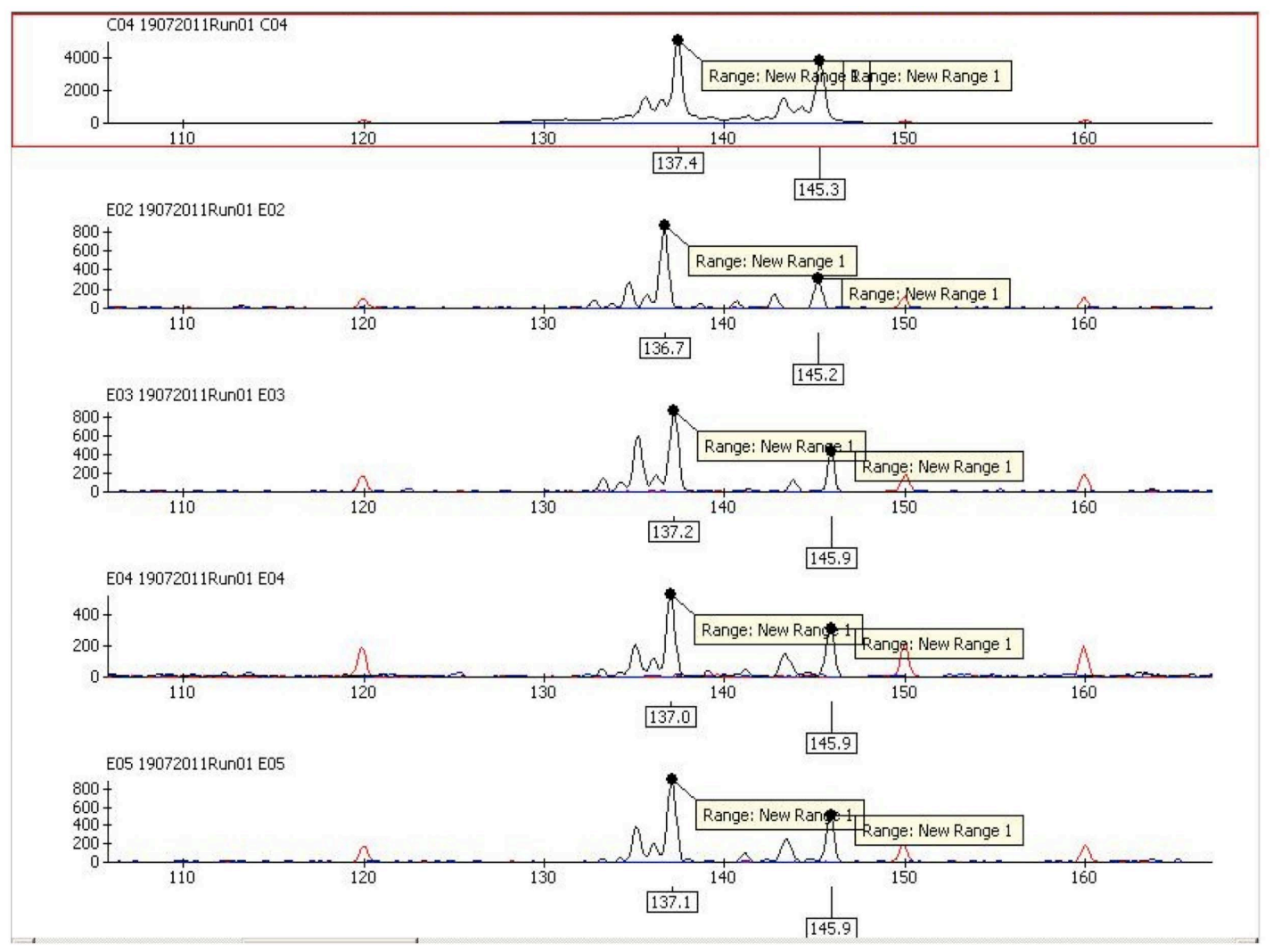

(a)
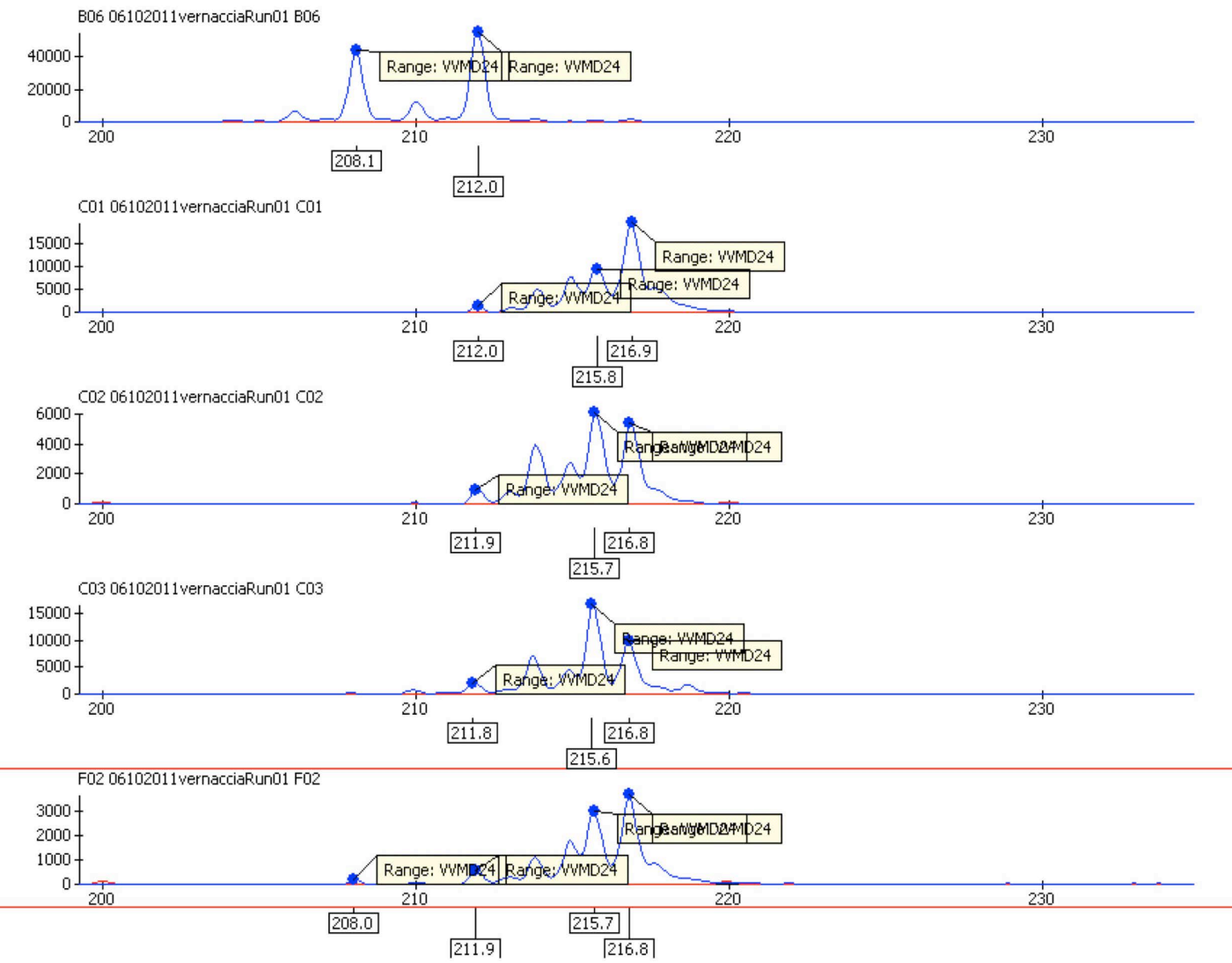

(b) 


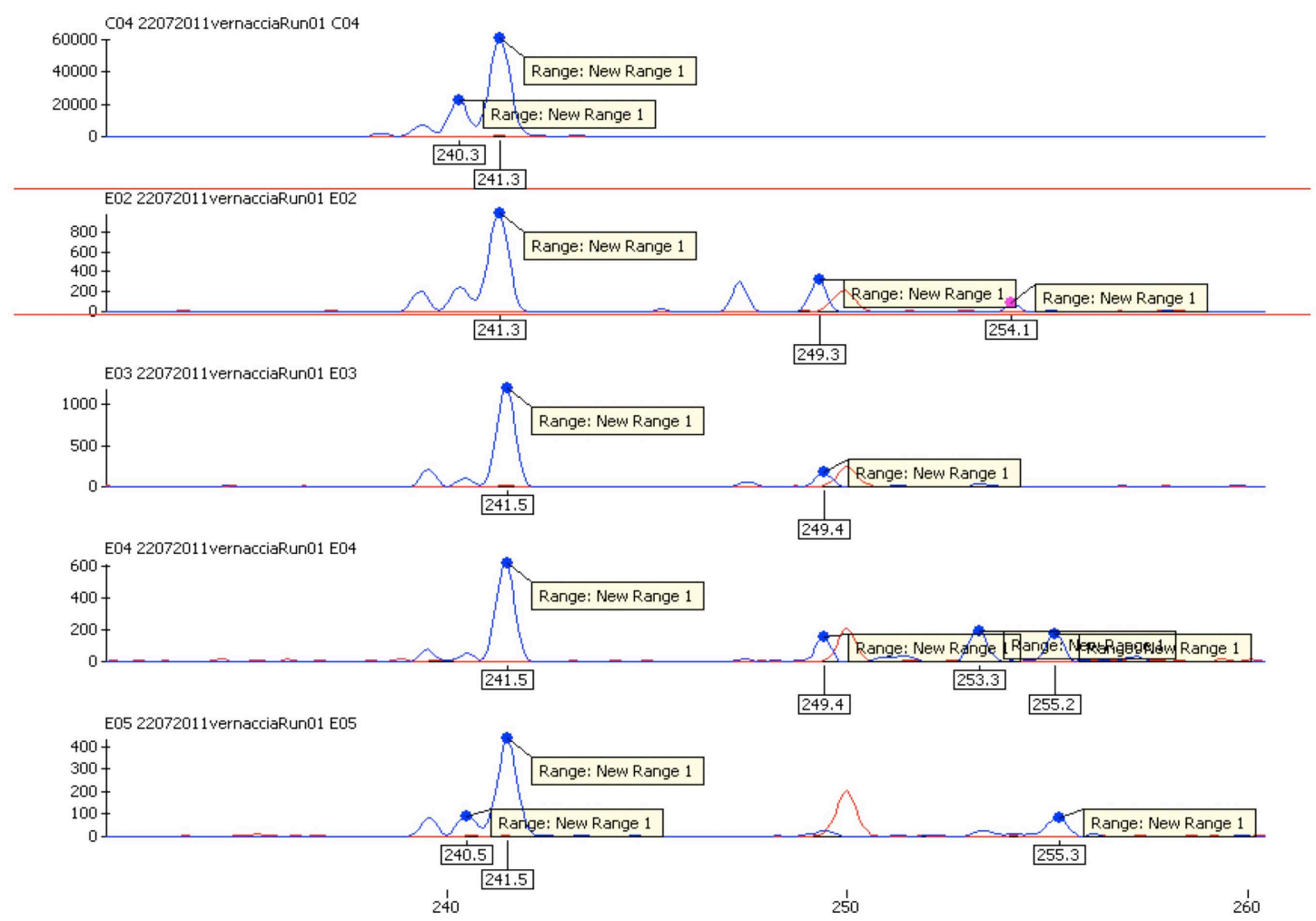

(c)
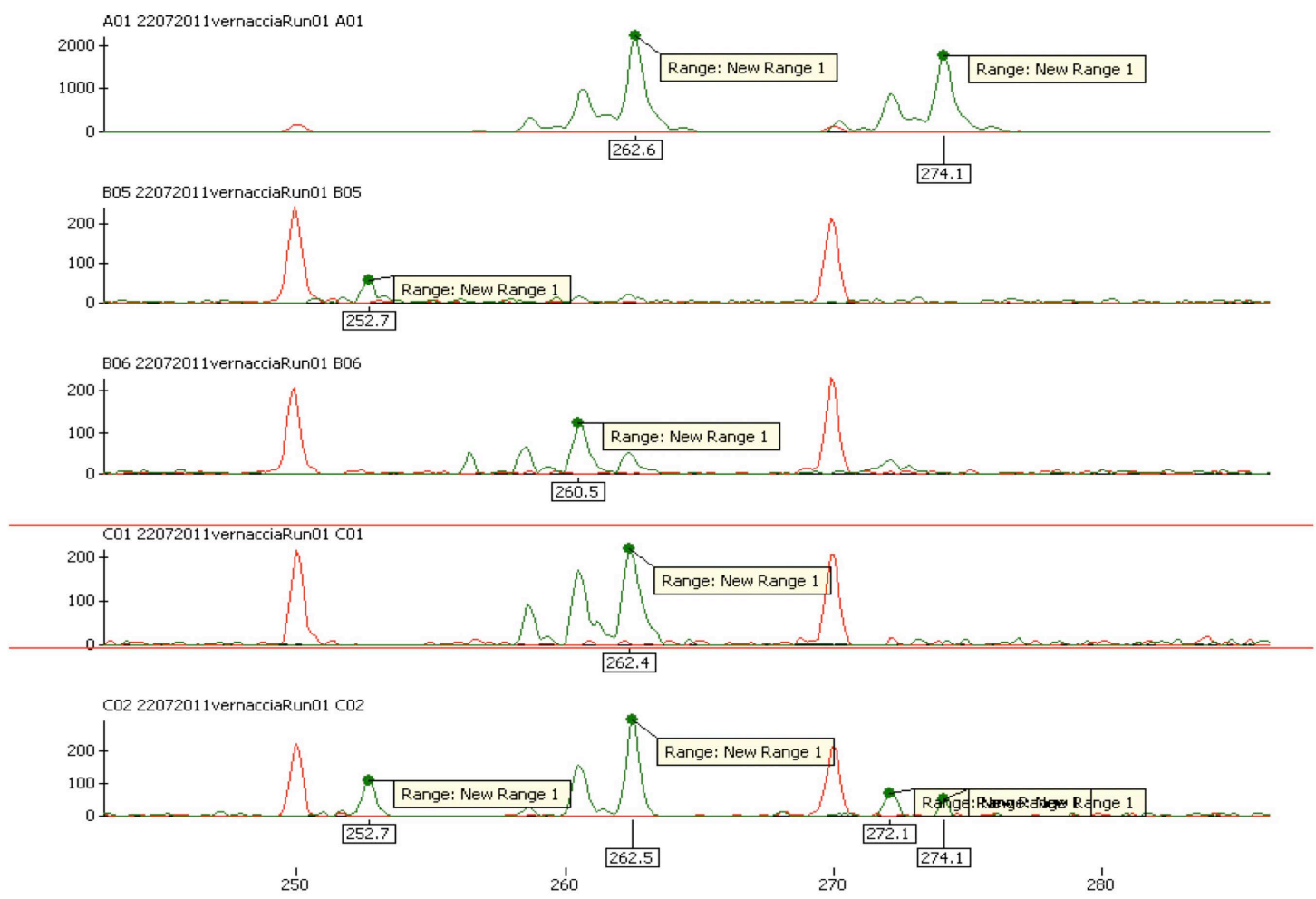

(d)

Figure 5. Electropherogram of the Vernaccia di San Gimignano (VSG) grapevine (always first from the top) and wines (from 1 to 4, from the top in each frame) amplified alleles respectively at locus VVS2 (a), VVMD24 (b), VVMD25 (c) and VVMD36 (d). At locus VVS2 only the major varietal component, the VSG, is traced, while at remaining loci, DNA fingerprints of the minor variety components, used for producing the blended wines are recorded. 
few years ago, the possibility of extracting genomic DNA residue belonging to the Vitis vinifera out of a complex matrix such as wine was strongly challenged and some research groups still argued that this may be a topic of research, the results of which could possibly reach the stage of application only in the future $[25,26]$. Indeed, even though in a fragmented scientific evidence in favor of the possibility of obtaining purified fractions of DNA from wine has taken place in the international scientific community as early as the 2000s $[17,27,28]$ which is followed by examples of uses in qualitative PCR and Real-Time fractions of the same nucleic acid species-specific recognizing $[16,29,30]$. Only recently, evidence has been produced that demonstrates that DNA from both experimental and commercial wines is not only removable with routine laboratory methods, but also usable for the reconstruction of the genotype of the variety that has been used for the production of wine with sufficient degree of statistical confidence [18]. On the subject of analytical traceability of wines, intended as support for certification and claims documentation already required by current regulations, there are several methodologies focused to respond to specific needs related aspects of authenticity and genuineness of the product. The two requirements for quality, geographical traceability and authentication of varietal identity, are the fundamental conceptual cornerstones for a certification of quality of the wine. The geographical traceability, at least by macrogeographic areas, is associated with isotopic analysis and information about the varietal composition has traditionally been addressed by chemical methods and more recently, by metabolomics. Unlike the methods based on the isotopic fractionation, which do not provide any indication about the identity of the variety, the chemical testing for varietal identification is strongly related to the grapevine varietal type, so that the intrinsic character of this method does not possess traits of universality. In greater detail, the chemical method involves the analysis of organic acids (shikimic acid) derived from classical methods [31], subsequently improved by the analytical point of view [32]. From the data reported in the literature, only a few varieties are recognizable in the wine. The enormous variability of chemical parameters would result by the intersection of complex phenomena already existing in planta and regulated by the interaction with the environment. The picture is further complicated by the intervening fermentation process carried out by yeast and bacteria and by the state of aging of the wine itself, which leads to processes of complexation between molecules and macromolecular breakage that produces many unknown molecular subfragments. Some of the varieties identified by the chemical method belong to the family of Pinot (P. noir, P. gris and $P$. blanc), if used to produce mono-varietal wines. A group of Chilean researchers have proven that it is very complex even for wines Merlot and Carmenere establishing a range of reference values for what concerns the acylated anthocyanins. In particular, the difference documented by Von Baer and collaborators [32], was observed for Merlot wines compared in the tank to the corresponding wines found in commerce. In the former, the ratio between the acylated anthocyanins and p-cumaryl containing compounds was significantly lower for $85 \%$ of the wines studied. Other studies [33] document the complexity of the phenomena that can make it difficult to build reference databases based on reliable measurement of chemical parameters. A recent work [34] efficiently describes the effects of the microbial population on the profile of Sangiovese wines, showing how it is possible to distinguish these wines from Merlot and Cabernet Sauvignon. In addition, the Sangiovese wines are indistinguishable following this analytical criterion in relation to the geographical derivation, vintage or brand. The last frontier of the chemical analysis of wines is represented by the generation by nuclear magnetic resonance or mass of metabolomic profiles, which has recently also been applied to Sangiovese [25]. Thanks to these recent developments, it's possible to photograph the chemical fingerprint of hundreds of organic compounds in a single analysis, compounds not only from varietal component, but also by fermentation that they must has undergone to transform into wine. In addition, the chemical analysis of coloured pigments could not be applied to white wines. It is perhaps because of these complex issues that geneticists of the grapevine have tried to develop molecular techniques to be applied to the issue of authentication of varietal wines. Given that the wine contains a prevalence of DNA derived from yeasts and bacteria are still debated, whether it is possible to effectively draw the DNA residuum from Vitis vinifera and if this is isolatable by routine analytical methods and, finally, if the information latent in the DNA molecule, presumably degraded due to the aging of wine and fermentation processes, are still used to infer the identity of the components of the wine varietal. The chemical and physical stability of the DNA molecule makes it an ideal candidate to establish associations between unknown genetic profiles and known standards either collected in local or international databases. In forensic medicine or in paleontology, the genetic identification using the techniques based on the amplification of species-specific DNA are used since the 80s, when the classic technique of nucleic acid amplification or Polymerase Chain Reaction (PCR) has become widely used. On these consolidated methodological references, it is based on the attestation of the current methods that based on DNA information, attests the varietal composition of a wine. While the technique based on the use of SSRs markers allows you to assign exactly an identifier 
profile of the variety in mono varietal wines, the cognitive framework for blended wines can be more complex, depending on the number of varieties used to make the wine, and their respective quantity. It is believed that in experimental wines produced from two varieties, the minor varietal component could be detected genetically up to a quantity of $1 \%$ (Vignani, unpublished results). Study cases where complex commercial blended wines produced out of over 20 varieties seem to allow the detection at the molecular level of main variety only, while the minor varieties could be traced, but not easily identified [35]. The VSG wines analyzed by SSR profiling revealed the presence of VSG and a few other minor varieties. The prevalence of the VSG is proved by the average higher peaks intensity that is associated to the VSG genotype with respect to other peaks that derive from alleles that do not belong to the VSG itself. The interpretation of wine mixed DNA profiles was done by evaluating the best allele combination that matched to a certain grapevine standard profile. To identify each cultivar in the wine, a minimum threshold value of 4 matching SSR loci was used. The current development of the technique allows a qualitative monitoring of the cultivar composition of a "plurivarietal" wine, as in the case of VSG wine, but the exact quantitative relationship between the cultivars used still remains unknown. Differently from other more traditional techniques for the varietal wine certification (chemical and metabolomics methods), the DNA analysis can count on robust international and local SSR databases and maintain a beneficial character of universality, being potentially able to identify each grapevine variety. In fact, the molecular traceability applied to the wine industry has its roots on the richness and variability of regional Italian autochthonous grapevine germplasm. This method is also potentially able to associate a given wine to its territorial origin, in the event that there are genetic variations in the vineyards (varietal ecotypes or biotypes). Currently, there are regulations in force in the European Union (UNI EN ISO 22005-certification and additional analytical product) that allow manufacturers to adopt voluntarily programs of control with specific objectives ratified by an independent third certification party and can therefore be expected also to enter molecular traceability plans to their vineyards and wines. The molecular tests are applied to the wine industry. On the one hand, an analytical basis to support control policies is made by the institutions and organizations involved in regulation policies. On the other hand if adopted voluntarily, the molecular testing done on vineyard and wines, is a formidable tool at the base of a marketing strategy and communication that enhances the characteristics of genuineness and compliance to quality of wines.

\section{ACKNOWLEDGEMENTS}

The present work has been done under a molecular traceability programme supported by the local government administration "Amminitrazione Provinciale di Siena” and the "Consorzio della Denominazione San Gimignano”. We sincerely thank Dr. Marco Lisi and Dr. Andrea Ciacci for their precious advice on history. We also thank Dr. Valerio Zorzi for his careful revision of the manuscript and QualiToscana for helping us in sampling the vineyards and keeping constant contact with the Vernaccia di San Gimignano producers.

\section{REFERENCES}

[1] Lisi, M. (2013) Sulle tracce della Vernaccia dal XIII al XXI secolo. Nuova Immagine Ed., Siena.

[2] D’Onofrio, C., Mattei, G., Scalabrelli, G. and Vignani, R. (2002) Caratterizzazione varietale assis-tita con marcatori molecolari delle Durelle autoc-tone della Lunigiana. Proceedings VI Giornate Scien-Tifiche SOI, Spoleto, 79-80.

[3] Scalabrelli, G., D’Onofrio, C., Ferroni, G. and Paolicchi, S. (2008) Uva vecchia. In: Il germoplasma viticolo toscano Vitigni ad uva Bianca. ARSIA, Florence, 201-204.

[4] Vergari D. and Scalacci R. (2008) Piero An-tonio Micheli Istoria delle viti che si coltivano nella Toscana. Firenze.

[5] Bruni, B., Breviglieri, N. and Casini, E. (1962) Vernaccie. In: I principali vitigni da vino coltivati in Ita-lia, Ministero Agricoltura e Foreste, Roma.

[6] Calò, A., Scienza A. and Costacurta, A. (2006) Vitigni d'Italia. Le varietà tradizionali per la produzione di vini moderni. Edagricole. Edizioni Agricole de il Sole, Bologna.

[7] Lulli, L., Costantini, E., Mirabella, A., Gigliotti, A. and Bucelli, P. (1989) Influenzadel suolo sulla qualità della Vernaccia di San Gimignano. Vignevini, 16, 53-62.

[8] Torello Marinoni, D., Raimondi S., Ruffa P., La-combe T. and A. Schneider (2009) Identification of grape cultivars from Liguria (north-western Italy). Vitis, 48, 175-183.

[9] Crespan, M., Armanni, A.B., Giannetto, S., Mene-ghetti, S., Randellini, L. and Storchi, P. (2010) Alla ricerca della corretta identità del Canaiolo bianco della Toscana. Proceedings of the 3rd Convegno Nazionale di Viticoltura, IASMAA, S. Michele All'Adige, Italy.

[10] Storchi, P., Armanni, A., Randellini, L., Giannetto, S., Meneghetti, S. and Crespan M. (2011) Investigations on the identity of "Canaiolo bianco" and other white grape varieties of central Italy. Vitis, 50, 59-64.

[11] Postollec, F., Falentin, H., Pavan, S., Combrisson J. and Sohier D. (2011) Recent advances in quantitative PCR (qPCR) applications in food microbiology. Food Microbiology, 28, 848-861.

http://dx.doi.org/10.1016/j.fm.2011.02.008

[12] Zago, M., Bonvini, B., Carminati, D. and Giraffa, G. (2009) Detection and quantification of Enterococcus gilvus in cheese by real-time PCR. Syst. Applied Microbiology, 32, 514-521. http://dx.doi.org/10.1016/j.syapm.2009.07.001

[13] Dong, W., Yang, L., Shen, K., Kim, B., Kleter, G.A., 
Marvin, H.J.P., Guo, R., Liang, W. and Zhang, D. (2008) GMDD: A database of GMO detection methods. BMC Bioinformatics, 9, 260. http://dx.doi.org/10.1186/1471-2105-9-260

[14] Chaouachi, M., El Malki, R., Berard, A., Romaniuk, M., LaVal, V., Brunel, D. and Bertheau, Y. (2008) Development of a realtime PCR method for the differential detection and quantification of four Solanaceae in GMO Analysis: Potato (Solanum tuberosum), Tomato (Solanum lycopersicum), Eggplant (Solanum melongena), and Pepper (Capsicum annuum). Journal of Agricultural and Food Chemistry, 56, 1818-1828. http://dx.doi.org/10.1021/jf073313n

[15] Scali, M., Vignani, R., Bigliazzi, J., Paolucci, E., Bernini, A., Spiga, O., Niccolai, N. and Cresti, M. (2012) Genetic differentiation between Cinta Senese and commercial pig breeds using micro satellite. Electronic Journal of Biotechnology, 15, 1.

http://dx.doi.org/10.2225/vol15-issue2-fulltext-1

[16] Savazzini, F. and Martinelli, L. (2006) DNA analysis in wines: Development of methods for enhanced extraction and real-time polymerase chain reaction quantification. Analitical Chemical Acta, 563, 274-282. http://dx.doi.org/10.1016/j.aca.2005.10.078

[17] Pereira, L., Pinto, H.G. and Lopes, P.L. (2011) An enhanced method for Vitis vinifera L. DNA extraction from wines. American Journal of Enology and Viticulture, 62, 547-552. http://dx.doi.org/10.5344/ajev.2011.10022

[18] Bigliazzi, J., Scali, M., Paolucci, E., Cresti, M. and Vignani, R. (2012) DNA Extracted with optimized protocols can be genotyped to reconstruct the varietal composition of Monovarietal wines. The American Journal of Enology and Viticulture, 63, 568-573.

http://dx.doi.org/10.5344/ajev.2012.12014

[19] Bowers, J.E., Dangl, G.S. and Meredith, C.P. (1999) Development and characterization of additional microsatellite DNA Markers for Grape. American Journal Enology and Viticulture, 50, 243-246.

[20] Thomas M.R. and Scott, N.S. (1993) Microsatellite repeats in grapevine reveal DNA polymorphism when analyzed as sequence-tagged sites (STSs). Theoretical and Applied Genetics, 86, 985-990.

http://dx.doi.org/10.1007/BF00211051

[21] Sefc, M.K., Regner, F., Turetschek, E., GlÖssl, J. and Steinkellner, H. (1999) Identification of microsatellite sequences in Vitis riparia and their applicability for genotyping of different Vitis species. Genome, 42, 367-373. http://dx.doi.org/10.1139/g98-168 PMid:10382286

[22] Bowers, J.E., Dangl, G.S., Vignani, R. and Merdith, C.P. (1996) Isolation and characterization of new polymorphic simple sequence repeat loci in grape (Vitis vinifera L.). Genome, 39, 628-633.

http://dx.doi.org/10.1139/g96-080

[23] De Mattia, F., Maitti, C., Imazio, S., Lovicu, G., Tardaguila, J., Grassi, F., Scienza, A., Failla, O. and Labra, M. (2006) Garnacha, grénache, cannonau, tocai rosso, vernaccia di Serra Petrona: Sinonimi o vitigno collettivo. In: I Vitigni Autoctoni Minori: Aspetti Tecnici, Normativi e
Commerciali, Fondazione per le Biotecnologie, Torino.

[24] De Mattia, F., Maitti, C., Imazio, S., Lovicu, G., Tardaguila, J., Grassi, F., Scienza, A.O., Failla and Labra, M. (2007) Garnacha, grénache, cannonau, tocai rosso, Vernaccia di Serra Petrona: Sinonimi o vitigno collettivo. Proceedings of the Symposium I Vitigni Autoctoni Miori: Aspetti Tecnici, Normativi e Commerciali, 28.

[25] Arapitsas, P., Peranzoni, D., Nicolini, G. and Mattivi, F. (2012) Study of Sangiovese wines pigment profile with UHPLC-MS/MS. Journal of Agricultural Food Chemistry, 60, 10461-10471. http://dx.doi.org/10.1021/jf302617e

[26] Grando, M.S. (2013) La tracciabilità del Brunello di Montalcino. Proceedings of the Symposium Traceability of Sangiovese at Montalcino, Siena, 24 May 2013.

[27] Siret, R., Boursiquot, J.M., Merle, M.H., Cabanis, J.C. and This, P. (2000). Toward the authentication of varietal wines by the analysis of grape (Vitis vinifera L.) residual DNA in must and wine using microsatellite markers. Journal of Agricultural Food Chemistry, 48, 5035-5040. http://dx.doi.org/10.1021/jf991168a

[28] Drábek, J., Stávek, J., Jalvková, M., Jurbek, T. and Frébort, I. (2008) Quantification of DNA during winemaking by fluorimetry and Vitis vinifera L.-specific quantitative PCR. European Food Research Technology, 226, 491497. http://dx.doi.org/10.1007/s00217-007-0561-8

[29] Faria, M.A., Magalha, R., Ferreira, M.A., Meredith, C.P. and Ferreira Monteiro, F. (2000) Vitis vinifera must varietal authentication using microsatellite DNA analysis (SSR). Journal of Agricultural Food Chemistry, 48, 1096-1100. http://dx.doi.org/10.1021/jf990837h

[30] Garcia-Beneytez, E., Maria, V.M., Joaquin, B., Maria, C.P. and Javier, I. (2002) Application of a DNA analysis method for the cultivar identification of grape musts and experimental and commercial wines of Vitis vinifera L. Using Microsatellite Markers. Journal of Agricultural Food Chemistry, 50, 6090-6096. http://dx.doi.org/10.1021/jf0202077

[31] Etiévant, P., Schlich, P., Bertrand, A., Symonds, P. and Bouvier, J. (1988) Varietal and geographic classification of French red wines in terms of pigments and flavonoid compounds. Journal of Science and Food Agriculture, 42, 39-54. http://dx.doi.org/10.1002/jsfa.2740420106

[32] Mardones, C., Hitschfeld, A., Contreras, A., Lepe, K., Gutiérrez, L. and von Baer, D. (2005) Comparison of shikimic acid determination by capillary zone electrophoresis with direct and indirect detection with liquid chromatography for varietal differentiation of red wines. Journal of Chromatography A, 1085, 285-292. http://dx.doi.org/10.1016/j.chroma.2005.06.022

[33] Mangani, S., Buscioni, G., Collina, L., Bocci, E. and Vincenzini, M. (2011) Effects of microbial populations on anthocyanin profile of Sangiovese wines produced in Tuscany, Italy. American Journal of Enology and Viticulture, 62, 487-494. http://dx.doi.org/10.5344/ajev.2011.11047

[34] Vignani, R. (2013) Wine varietal authentication by use of DNA analysis. International Wine Technical Forum, Canandaigua, 28 April-2 May 2013. 